\title{
THE OPERATION OF THE CITY CLEARING HOUSE
}

\section{FLETCHER R. ANDREWS $\dagger$}

PrIor to the establishment of the clearing house, banks within a given city collected checks from one another by individual messenger. ${ }^{1}$ This meant that the messenger from bank $A$, for example, would personally present to each other bank in the city the checks which bank $A$ held against it, and would receive from the drawee bank the total amount of money represented thereby. At the same time, messengers from the other banks were engaged in like activity. In a city like New York, containing fifty-two banks, ${ }^{2}$ it may readily be appreciated that this complex system consumed an inordinate amount of time and created a veritable plaguc of bank messengers descending daily upon each institution. ${ }^{3}$ Furthermore, the bookkeeping burden was appalling. Each of the fifty-two banks maintained an account with each of the other fifty-one. Credits and debits had to be entered daily, in addition to the accompanying deposit slip and passbook entries on each account. ${ }^{4}$

Other serious disadvantages arose from the custom of paying in specic. Although the New York banks substituted weekly for daily settlements, the process still caused extreme confusion on settlement day. In addition, the system involved the risk attendant upon carrying cash, and the freezing of currency arising from the necessity of keeping enough on hand to meet the demands of the other banks. ${ }^{6}$ As the volume of checks increased, the situation grew more and more intolerable, and it became

$\doteqdot$ Professor of Law, Western Reserve University Law School. Sterling Fellow, Yale Law School, 1938-39.

1. See Spatr, The Cleartng and Collection of Checks (1926) 73. This paper deals only with the collection of local items, not with out-of-town items. In other words, it is limited to the method whereby a bank collects checks drawn upon other banks in the same city. Of course, the check may have come to the collecting bank from another city, but if the collecting bank and the drawee bank are in the same city, the item is local.

2. See Hallock, Clenring Out-0F-Town Checks (1903) 5. The authorities consulted are not in agreement about the exact number of banks, doubtless because their counts were made at different times. For the purposes of this paper, it is not essential to determine which is correct. Fifty-two is the lowest number given.

3. A subsequent arrangement in New York whereby only half the banks sent out messengers during a six-months period and the other half during the stecceding six months effected only partial alleviation. See ibid.; SpAHR, op. cit. supra note 1 , at 80 .

4. See Cleaveland, Banking System of New York (1857) 266.

5. See Hallock, op. cit. supra note 2, at 7.

6. See Agger, Organized Banking (1918) 29; Clesveland, op. cit. supra note 4, at $267 ; 2$ Conant, Principles of Money and Banking (1905) 242. 
essential to find an adequate remedy. Out of this need was horn the clearing house. ${ }^{7}$

\section{The Origin and Development of the Clearing House}

Before tracing the origin and development of the clearing house, it will be helpful to understand in a general way the nature of clearing and the clearing house, leaving a more detailed treatment until later. Reduced to its basic terms, the clearing of checks consists of a setting off of debits against credits. ${ }^{8}$ The simplest example occurs where only two banks are involved. Suppose that bank $A$ holds checks on bank $B$ amounting to $\$ 100,000$, and bank $B$ holds checks on bank $A$ for $\$ 50,000$. Suppose, further, that representatives from each bank meet, exchange one another's checks, and debit or credit one another's account, as the case may be. At that point the checks are said to have been cleared, although obvinusly payment has not yet taken place. ${ }^{9}$ The representatives then return, each to his respective bank, where the checks drawn on that bank are examined for genuineness of signature, amount on deposit to the drawer's credit, and so forth. If all the checks are found to he gond, bank $B$ then owes bank $A \$ 50,000$, which bank $B$ will pay in accordance with the existing arrangement between the two banks. This elementary illustration not only serves as a guide to the clearing process, but also points out the distinction between clearing and payment. Complications resulting from the discovery that some of the checks are bad will be considered later.

An increase in the number of banks does not alter the fundamental principle of clearing, but, of course, affects the mechanics of the operation. Thus, suppose there are four banks instead of two. If each bank sends its checks to a common meeting place, where the checks are exchanged and proper debits and credits made, a clearing of the checlss will have occurred. The organization composed of the member banks which have associated themselves together for the purpose of effecting

7. Professor Spahr furnishes an illuminating example of the impracticability in modern times of intracity check collection without a clearing house. He asserts that on December 16, 1919, the transactions at the New York Clearing House amounted to $\$ 1,519,848,984$. Had it been necessary to transport gold to meet all claims presented that day, 410.7 five-ton trucks would have been required. Sp.rms, of. cit. sufira nate 1 , at 405 . Settlement in bank notes, while an improvement, was no cure.

S. "The clearing system is a development of a principle of Roman commercial law known as compensatio-the setting off of a debt which one owes tn another hy a claim against him." 2 ConANT. op. cit. supra note 6 , at 239.

9. Payment does not take place until the drawee bank has hien given sufficient time to determine whether the check is guod. See Tallert. Clcarine-Housc and Demestic-

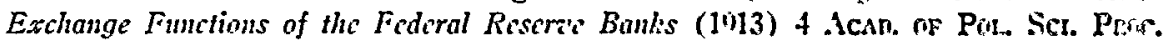
$192,193$. 
the exchanges is known as the clearing house, and this term is likewise applied to the place where the clearings are made. ${ }^{10}$

During the Middle Ages the clearing house idea attained a high degree of perfection, although apparently it was not then used among banking houses within a single city. The great fairs, especially those at Lyons, were the scenes of these clearing operations. Louis XI, by the ordinance of March 8,1463, authorized four fairs per year at stated intervals. Each fair was followed by a day of settlement fixed at the preceding fair. To these came the bankers, each with his balance sheet of debits and credits. The settlements contemplated three steps: first, acceptance by each drawee of the bills of exchange drawn against him; secondly, comparison of the accounts; and, finally, settlement in money. The adoption of the clearing principle reduced to a minimum the amount of moncy needed for settlement. Although quarterly settlements at Lyons continued until 1793, the fairs at Placenzia surpassed those at Lyons in importance during the latter part of the sixteenth and beginning of the seventeenth century. In fact, the fairs at Placenzia became the clearing house of Europe. ${ }^{11}$

According to Mr. Conant, the translation into many tongues of Savary's Le Parfait Negociant served in the eighteenth century to disseminate throughout Europe knowledge of the methods of clearing practiced at Lyons. ${ }^{12}$ But whether this knowledge seeped through to the bank messengers whose fertile brains sired the London clearing house does not appear. It seems more likely that these messengers were actuated by their own convenience rather than by any influence of Savary.

Although there is evidence of earlier clearing arrangements between Edinburgh banks, ${ }^{13}$ it is generally conceded that the genesis of the clearing house of today took place in London. The events leading to the formation of the London clearing house are interesting and not without their share of amusement. A situation existed similar to that already described with reference to New York at a later clate. Clerks from the various banks made the rounds of the other banks, presenting and collecting checks and other items, with resultant waste, risk, and stag-

10. For definitions of clearing, see Cannon, Clearing Houses (1910) 4; Kenmerer, The ABC of the Federal Reserve System (1932) 79 n.; Spair, op, cil. supra note 1, at 67; Westerfield, Banking Principles and Practice (rev. ed. 1928) 462; Willis \& Edwards, BANKING and Business (rev. ed. 1925) 236, 240, 249. Iior definitions of a clearing house, see CANNON, op. cit. supra, at 1; HARR \& HAkRIS, BANRing Theory and Practice (2d ed. 1936) 234; 2 MLcteod, Treoky of Crentt (1890) 380; WESTERFIELD, op. cit. supra, at 461.

11. For an account of clearance at the fairs, see 2 CoN $\Lambda N$, op. cit. supra note 6, at 239; (1891) 5 BANK. L. J. 352, $353 \mathrm{n}$.

12. See 2 Conant, op. cit. supra note 6 , at 240 .

13. See ibid.; Jones, Clearings and Collections; Foneign and Domestic (1931) 21; Spanr, op. cit. supra note 1, at $71 \mathrm{n}$; (1891) 5 BANk. L. J. 352, $353 \mathrm{n}$. 
nation of cash. ${ }^{14}$ But the real stimulus to the development of the clearing system did not arise from these evils. Indeed, it did not come from the employer or management side at all. Rather, it was the result of a natural desire on the part of the clerks to avoid tramping from bank to bank and being compelled to wait while each bank verified the checks drawn on it. In furtherance of this desire it became customary for the clerks to meet and exchange one another's checks. Each clerk made his own exchange with each other clerk, and, at a subsequent mecting, individual settlements were made between each pair of banks. ${ }^{15}$

This method of individual exchange and settlement was destined to oblivion because of the fact that it involved so much waste mution, and it was not long before the clerks remedied the situation by appointing two or three of their number to handle all the paper. Under this arrangement the clerk of each bank delivered to the clearing clerks all the items which he held against the other banks. The clearing clerks sorted the batches according to drawee banks and delivered to each clerk the batch of items drawn on his bank. ${ }^{16}$

Apparently the employers gave no official sanction to the clerls' clearing procedure for some time after its inception. Finally, however, they rented a private room for the clearings, but there is no evidence to indicate any formal organization or association at the time, and, evidently, the clerks were left to their own devices, unhampered by any rules. In 1805, however, a committee of bankers promulgated a set of rules for the clearing procedure, and in 1821 a permanent committee was appointed to assume the management of the clearing house. ${ }^{17}$

In 1833 the permanent building known as the clearing house was erected. Those in charge did not want a pretentious structure. As a result, the clearing house was so constructed and so placed as to be practically unknown to and unnoticed by the general public. This policy uf self-effacement arose from a desire that the clerks, who were uften carrying large amounts of Bank of England notes and other muncy and

14. See Seyd, Londox B.ming and Bankers' Cueiring Hotse Sistes (1873) 40.

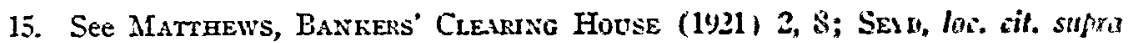
note 14; (1891) 5 B.ANk. L. J. 352, 353. The early meetings twok flase in a tavern lnown as the "Five Bells," where, according to one writer, the elerks "met to liyuity" their parched throats and where incidentally they found by experience that it was pisssible and advantageous to liquidate also their principals' accusunt:" Zullman. P'ar Clcarance in the Federal Reserie System (1925) $10 \mathrm{MAng}$. L. Res. 134. Ealances were fratil in bank notes and coin. See HoDder, Work of a B.ANK (5th wl. 1930, 115.

16. See (1891) 5 Bank. L. J. 352, 353.

17. See MatrHews, op. cit. supra nute 15 , at $\$$. The tavern mcetings protably were in full swing by 1770 . The London clearing houe was fuunded about 1773. Sec Sr.unt, op. cit. supra note 1 , at 71 . 
securities, should attract as little attention as possible. ${ }^{18}$ Plainly, the fewer who knew the whereabouts of the clearing house building, the less conspicuous would be the entrances and exits of its dramatis personnac. ${ }^{10}$

Unlike the situation in London, the clearing house in the United States did not originate through employee torpor - at least so far as may be discovered from the authorities examined. Although, as previously stated, banks customarily collected their local checks by messenger before the establishment of the clearing house, instances are known of clearing relations between small groups of banks. ${ }^{20}$ There is no intimation, however, that these cooperative efforts had their inception in the extra curricular activities of the bank messengers.

Although New York organized the first clearing house association in the United States, Philadelphia had taken steps to simplify city clearings and collections by 1852 , a year earlier than the formal establishment of the New York Association. ${ }^{21}$ The first formal proposition to establish a clearing house in New York came from the pen of Albert Gallatin, president of the National Bank, which later became the Gallatin National Bank. He published a pamphlet urging the formation of a clearing house. ${ }^{22}$ Extremely important was his recommendation that clearing house balances should be settled by debits and credits against deposits of specie to be made by each bank, thus eliminating the use of cash.

Like most reform proposals, the establishment of a New York clearing house was subjected to a long period of consideration, and the banks took no definite action for a number of years. At length, the Mechanics' Bank invited the officers of the various banks to a meeting to consider the matter. The meeting took place on August 23, 1853. ${ }^{23}$ Recognizing the necessity for some change in the method of collecting local checks, the participants, conforming to the traditional procedure in such cases,

18. See Matrhews, op. cit. supra note 15 , at 12.

19. For a list of other clearing houses in England, see 1 HART, LAW of BANkind (4th ed. 1931) 430.

20. See SPAFr, loc. cit. supra note 1.

21. See SPAHR, op. cit. sitpra note 1 , at 80 .

22. See The New York and London Crearing House Systems (document published in 1885 by The Financier Company) 1; Simmonds, Why a Clenringuouse Association? (document published by the Clearing House Section of the American Bankers Association) 3.

23. See Cleaveland, Banking Systen of New York (1857) 268. A pamphlet issued by the New York Clearing House Association in 1938, Infokstation Regandring the Operation of The New York Clearing House, gives a clue as to why the protracted dreams of a clearing house so suddenly achieved reality. On page 1 it is stated: "Between the years 1849 and 1853, the number of banks in New York City increased from 24 to 57, this following the increase of business incident to the discovery of gold in California, and this increase in the number of local banks made it very necessary that some plan be worked out which would bring about a more prompt settlement of balances between banks." 
roted to appoint a committee to consider the problem and report back with a plan. The ultimate result was the organization of the New York Clearing House Association on October 4, 1853, and the beginning of clearing house operations under the direction of a committee appointed by the associated banks. ${ }^{24}$ For nearly a year the clearing house operatel without a constitution. On June 6,1854 , a committee adopted a pruposed constitution. This was sent to the member banks for their consideration, and on August 1, 1854, became effective. ${ }^{25}$

By 1925 there were clearing houses in all the principal financial centers of the world, the United States having at least three hundred and sixtytwo. ${ }^{26}$ Early in the present century the clearing house and its problems were deemed of sufficient importance to warrant the creation of a Clearing House Section of the American Bankers' Association, ${ }^{27}$ and this Section continued until 1929, when the Association abolished it and substituted the Commission on Banling Practices and Clearing Hlutuse Functions. ${ }^{28}$ This Commission is now known as the Bank MIanagement Commission, and its functions have been considerably broadened. ${ }^{20}$

24. See Cleaveland, loc. cit. supra note 23. The date is taken from the tille pisge of the Constitution of the New York Clearini; House Assuctiting 1 Oet. 5, 1937 .

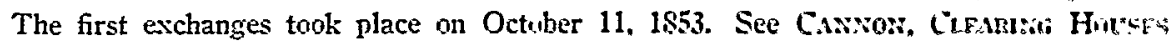
(1910) 154. For a list of the 52 original members, see the Cosstirtums, cited sufra, at 24 .

25. See Cavion, loc. cit. supra note 24 . Chapter 13 uf this bums contains a complete account of the history and organization of the New York Clearing House.

26. See Whils \& Epwaris, Banking and Business (rev. cd. 1925) 237. A letter, dated May 9, 1940, from the assistant secretary of the Bank Management Cummissin, of the American Bankers Association, gives 351 as the number of city clearing houss in the United States at that date. The writer of the letter states that the number of clearing houses has remained relatively constant during the past few years. For the dates of founding of clearing houscs other than New York's, see Caswos, of cif. suspra note 24, at 277; SPAHR, op. cit. supra note 1, at 71. For an extended treatment of the form3tion and organization of some of these, see CANsun, chapters $15 \mathrm{at}$ scl.

27. See (1906) Proc. Am. Baniers Ass's 103; (1909) Prase Clearazo Hox $\rightarrow$ : Section, Asr. Baxkers' Ass'x 4. Even hefore the establishment of the Clcaring Houss Section, representatives from the clearing house assuciations lield annual contierences in conjunction with the American Bankers' Association convention. Clevelant, Ohio, was the scene of the first of these conferences in 1599. At that meeting the associations effected a formal organization. In 1905 the Amcrican Bankers' Association ofticially recognized the organization by appointing a special committee to supervise the work of the clearing house conferences. In 1906 the American Bankers' Association established the Clearing House Section. See Spanr, op. cit. supra note 1, at 137. In 1918 the Clearing House Section reported that for the first time in its existence its membership included every regularly organized clearing house association in the United States. (1918) Pros: ANr. Bankers' Ass'is 243.

28. See (1930) 22 J. Asr. Bankers' Ass's 300.

29. The reasons for the substitution of the Commission for the Clearing House Scetion, together with the general nature of its expanded scope, are set forth in the preface to a manual prepared by the Committee on Clearing Huuses of the Bank Management

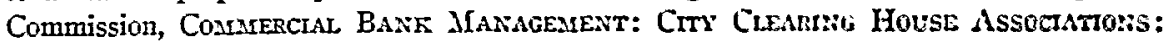
Mantual of Organization and Managearent. 
No outline of the development of the clearing house would be complete without a glance at some of the more important statistics. In 1868, the first year for which figures were published, the London Bankers' Clearing House had average daily clearings amounting to $£ 10,978,200$. By 1898 the daily average had increased to $£ 26,289,900$, and by 1920 to $\left\{129,224,7000^{30}\right.$ As for the New York Clearing House, the total clearings on October 11, 1853, the first day of its operation, amounted to $\$ 22,648,109.87 ;^{31}$ and for the fiscal year ending September 30, 1854, the average daily clearings amounted to $\$ 19,104,504.94$. Contrast with this the average daily clearings for the following years:

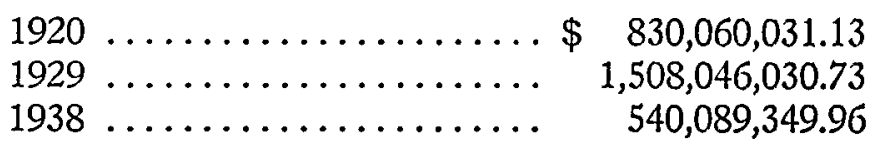

The figures demonstrate the astonishing increase in the volume of check clearing since the comparatively humble beginnings of the clearing house, and bear witness to the impracticability of collection by messenger under modern conditions. ${ }^{32}$

Before entering upon the details of the clearing routine, some attention should be given to the organization of clearing houses. Nlthough exceptions may exist, clearing house associations are generally unincorporated. ${ }^{\text {s3 }}$

30. See Matthews, Tie Bankers' Clearing House (1921) App. III. Skyd, LonDon Banking ANd Bankers' Clenking House. System (1873) 45-46, states that in the year 1870-71 (apparently referring to a fiscal year) a total of more than $£ 4,000,000,000$ passed through the clearings. Compare with this the amount represented by bills and checks cleared in 1926, which, according to Mr. Chalmers, amounted to $439,825,054,000$. Chalamers, Bills of Exchange (9th ed. 1927) 173. Mr. Seyd, on page 46, states that the number of checks passing daily through the clearings at that comparatively carly date ranged between 60,000 and 80,000 . On the same page he advances the following astonishing information: "Some time ago, the total length of the lists of Cheques of one of the Bankers, written up very closely, for the purpose of addition, measured to less than 300 feet."

31. See Cannon, Clearing Houses (1910) 154; Moulton, Money and Bankina (1921) pt. 2, p. 102. This figure is verified in a New York Clearing House panphlet containing extracts from the manager's annual report for the year ending September 30, 1938.

32. The figures are taken from the pamphlet referred to in the previous footnote, which contains the statistics from the opening of the clearing house through the fiscal year 1938. The total clearings per year are equally revealing. See Smyth, The Ncw Yor/: Clearing House (1891) 5 BANk. L. J. 99, 103, for an amusing calculation based on volume of clearings. Clearings of the New York Clearing House represent about 54\% of the total clearings for the entire United States. See Information Regarding the: Ortuh * tron of THE New York Clearing House (pamphlet issued by the New York Clearing House Association, 1938) 2.

33. There is probably nothing to prevent their incorporation as corporations not for profit, but this depends upon the law of the particular state. The law of Texas specifically permits their incorporation. Tex. Ans. Rev. Civ. Stat. (Vernon, Supp. 1041) art. 1302 (54) (enumerating the powers of such corporations). In a letter of April 12, 
They are voluntary associations, whose members are bound by the constitutions, by-laws, rules, and regulations which they have adopted. Since there is no carrying on of a business for profit, these associations are not partnerships. ${ }^{34}$

Although many of the provisions in the constitution and other regulations of the typical clearing house association will be considered in connection with specific problems, a brief resume at this point may be appropriate. For this purpose the New York Clearing House Assuciation has been selected. ${ }^{35}$ The members of that association are governel by a constitution and a set of rules, regulations, and rulings, the latter conlsisting chiefly of rules adopted by the Clearing Iouse Committee for the interpretation and enforcement of the constitutional provisions.

The constitution sets forth as the objects of the association settlement of the daily exchanges at one place, payment of balances, promotion of the interests of the members, and maintenance of conservative banking through wise and intelligent cooperation. It provides that the association shall not be responsible for the exchanges or the resulting balances, responsibility being confined to the distribution among the creditor members of the sums received from the debtor members. Any loss occurring while the balances are in the custody of the clearing house manager or his assistants is to be borne by the members in certain designated proportions. Admission to membership is carefully restricted, ${ }^{\text {s6 }}$ and members are required to comply with a number of stipulations looking toward safe and conservative banking. As might be expected, an

1940, the assistant secretary of the Dallas Clearing House Assuciation informed me that his association is incorporated. Presumably, clearing houses are mure free to carry out their objects unhampered by government restrictions if not incorporated. See Houston, Uniformity of Clearing House Rules and Pratices (1919) Pros. Clevang Huuse Sec., Axr. Bankers' Ass'x 492, 498; (1892) 6 Baxk. L. J. 187. As to whether a n3tional bank may become a member of a clearing house association, sce MAGEe, LAw of National and State Banks (3d ed. 1921) 636, and cases there eited. The right of banks to associate themselves together in a clearing house organization is unquestionsu. See Security Comm. \& Sav. Bank of San Diego v. Southern Trust \& Cumm. Bank, 74 Cal. App. 734, 742, 241 Pac. 945, 948 (1925), and cases there cited.

34. See (1892) 6 Bank. L. J. 187, 188.

35. In connection with the preparation of this article, I obtained cunstitutions, bylaws, rules, and regulations from a number of clearing houses. It is decmed unnecessary to make specific references to these. In general, they follow the pattern of the New York Association. For the rules of the London Bankers' Clearing House, see Grani,

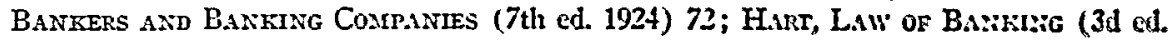
1914) 352. For the original constitution of the New: York Clearing House Association, see Cleaveland. Banking System of New Yonk (1857) 278. For the rules of various Canadian clearing houses, see Falcondninge, Banking and Bhrs of Excrusice (5th ed. 1935) 409-25.

36. E.g., most associations refuse to admit an institution whose unimpired eapital is below a designated figure. 
admission fee is generally exacted, and the members share the expenses of operation.

There are the customary provisions regulating meetings and defining the duties of officers and committees. To the Clearing House Committce is delegated the general management of the clearing house, including the power to prescribe rules and regulations to be observed at the clearing house. Supervision is placed in a manager who has charge of the building and the transaction of clearing house business, subject, of course, to the rules governing the actual operation of the exchanges and the settlement of balances.

\section{The Clearing House Technigue}

General Description. Although the mechanics of clearing may vary in minor details in the clearing houses of the United States, the procedure is fundamentally the same. ${ }^{37}$ The clearing process of the New York Clearing House will be used as an illustration.

In preparation for the clearing, each bank sorts into separate pilcs the checks which it holds against the various drawee banks. The checks against each drawee bank are then listed and the total against each ascertained. Each bundle of checks is then placed in a large envelope bearing the name of the applicable drawee bank. To each bundle is attached the total amount and the list of the enclosed itens. This list is known as the "exchange slip."

Certain other memorandum slips are also prepared. One is known as the "small ticket." A separate "small ticket" is made out for each drawee bank. The ticket contains the name of the drawee bank, the name of the claimant bank, and the total amount claimed. The latter amount obviously is the sum of the items to be presented for payment. Another slip is known as the "first ticket." Upon this appear the name of the claimant bank and the total amount of its claims for the day. This last figure of course is obtained by adding together the amounts claimed against the respective drawee banks. Finally, there is the "delivery clerk's statement." The first column of this document consists of a list of the clearing house banks arranged in the order of their respective clearing

37. See (1892) 6 BANK. L. J. 32, 34, noting that the method of clearing in the large cities is substantially similar to that in operation in New York, but that in the smaller citics the making of the exchanges does not involve such a detailed process. An cxample of this less detailed procedure is contained in the Syracuse Clearing House Association by-laws, which provide that the messengers from the banks shall present their itents to the clearing house clerk, who shall make delivery to the respective drawce banks. For interesting variations in the procedure used in different clearing houses, sce CANNON, Clearing Houses (1910) 52. In general, see also Hark \& Hakrts, Banking TukouY ANd Practice (2d ed. 1936) 235; SpaHR, op. cit. supra note 1, at 393. On bank organization for clearing and collection, see SPAHR, op. cit. supra note 1, c. 11. 
house numbers. ${ }^{38}$ To the right of the name of each bank appears the total amount of the claim against it together with a space for the signature or initials of the clerk receiving the claim.

- Each member bank sends to the clearing house a delivery clerk and a settling clerk. The delivery clerk presents the items to the representatives of the drawee banks; the settling clerk receives the items drawn upon his bank. Upon arrival at the clearing house the representative of the bank delivers his "first ticket" to the clearing house proof clerk, whose functions will be explained presently.

Upon the floor of the clearing house, desks are arranged in rows, each bank being assigned a desk. The settling clerk takes his position in a cage behind the desk assigned to his bank. The delivery clerk stands in front of the desk. Upon the sounding of the signal each delivery clerk moves to the desk next to his own. There he leaves with the settling clerk of the particular bank the envelope containing the items drawn against that bank, the "exchange slip," and the "small ticket." $\mathrm{He}$ also presents to the settling clerk his "delivery clerk's statement," and obtains the signature or initials of the settling clerk opposite the amount listed against that bank. This constitutes a receipt for the items delivered. After he has finished at the first desk he proceeds to the next and so on until he has completed the circuit. It will be seen that all the delivery clerks are engaged in this process at once, advancing one after another from desk to desk. It is apparent that after the clerks have made the rounds, the delivery of all the items will have been effected. This whole pilgrimage consumes but a few moments.

After the exchanges have thus been received, each settling clerk prepares his statement. The first column consists of a list of the banks. The second column contains the amount of the claim against each bank. The data for this column was entered prior to the departure of the clerk for the clearing house. Farther to the right is a column in which the settling clerk enters opposite the name of each bank the amount of its claim against his bank. He obtains this figure from the envelope and "small ticket" handed to him by the delivery clerk of the claimant hank. Presumably the column setting forth the claims ayainst other banks already has been added. The settling clerk totals the column showing claims against his bank and proves it against the total sum represented by the "small tickets." He then takes the difference between the two culumn totals, which gives him the position of his bank as a result of the clearing. For example, if the amount due his bank is $\$ 100,000$ and the amount of claims against his bank $\$ 150,000$, his banl is a debtor to the clearing house in the amount of $\$ 50,000$. The two totals and the debit

38. For convenience a clearing house number is assigncd to each bank. For a description of the country-wide numerical system see SHAH, ap. cil. supra nute 1 , at 458 . 
or credit balance are entered upon a "second ticket" by the settling clerk. This "second ticket" is delivered to the clearing house proof clerk. Meanwhile, the delivery clerk has returned to his bank with the envelopes containing the checks drawn against it.

The clearing house proof clerk prepares the proof of the day's work. It will be recalled that upon arrival at the clearing house the representative of each bank handed to the proof clerk his "first ticket," showing the total amount of his bank's claims. From the "first tickets" the proof clerk enters upon the clearing house proof sheet the amount brought by each bank. This he may do before the completion of the exchanges. Upon receipt of the "second tickets" from the settling clerks, the proof clerk prepares the remainder of his proof sheet. In one column he enters opposite the name of the bank in question the total claims against it. This figure he obtains from the "second ticket." $\mathrm{He}$ then enters opposite the name of each bank its debit or credit balance for the day. In the absence of mistake, the column containing the amounts brought must equal that containing the amounts received, and the column of debit balances must equal that of credit balances. ${ }^{30}$ If the figures do not balance, the clerks set to work to discover the error. The rules of the New York Clearing House Association allow forty-five minutes from the beginning of the clearing for a proof. If the proof is not made within that time, banks whose errors are responsible for the delay are fined in accordance with a fixed schedule.

Although in the early days of the clearing house one exchange a day was doubtless sufficient, the growing volume of business in some cities has required an increase in the number of exchanges. In the New York Clearing House Association, for example, the main clearing takes place at 10:00 A.M., but additional exchanges have been provided. The constitution requires that, at not later than 2:00 A.M., items received between the previous day's 10:00 A.M. clearing and the close of the day's business be delivered to the clearing house for exchange. Provision is also made for optional exchanges at 8:00 A.M. and 9:00 A.M. The clearing house

39. The body of the New York Clearing House Proof is substantially as follows:

\begin{tabular}{|l|l|l|l|l|l|}
\hline No. & Members & $\begin{array}{c}\text { Debit Balances } \\
\text { Due Cl. House }\end{array}$ & $\begin{array}{c}\text { Debit } \\
\text { Amts. rec'v'd }\end{array}$ & $\begin{array}{c}\text { Credit } \\
\text { Amts. brought }\end{array}$ & $\begin{array}{c}\text { Credit Balances } \\
\text { due members }\end{array}$ \\
\hline & & & & \\
\hline & & & & \\
\hline & & & & \\
\hline & & & \\
\hline
\end{tabular}

For a facsimile of the form, see MUUNn, Encyctopedia of Banking and Financr (4th ed. 1937) 164; SPAHR, op. cit. supra note 1 , at 401 . 
manager or his representative is required to be at the clearing house between 12:01 A.M. and 3:00 A.M., and between 8:00 A.M. and 9:00 A.M., to deliver to the representatives of the several banks any packages held against them. A number of the other clearing house associations whose regulations were studied also make provision for preliminary clearings. In these, as well as in the New York Clearing House, no proof is struck at the preliminary clearings, their purpose being to lessen the congestion by affording to the banks additional opportunities to exchange items. The amounts cleared at these preliminary exchanges are charged through the succeeding main clearing. For example, suppose that at the preliminary clearing the $A$ bank delivers items against the $B$ bank in the amount of $\$ 50,000$. This sum will then be added to the amount claimed against the $B$ bank by the $A$ bank at the regular clearing, and will be evidenced by a receipt or ticket obtained at the preliminary exchange. ${ }^{40}$

Settlement of Balances. After completion of the proof the various balances resulting from the day's exchanges are settled. ${ }^{41}$ The exact time for settlement is prescribed by the regulations of the several clearing houses, and is shortly after the proof has been made. The most obvious method of settling balances is for the debtor banks to bring to the clearing house in actual specie or other currency the amount owed, and this was the scheme followed in the early days of the New York Clearing House.92 But such an arrangement entailed risk and serious inconvenience. ${ }^{43}$

40. The items eligible for clearing are governed by the regulations of the several clearing house associations. In general, the following are included: checks, bills of $\mathrm{ex}$ change, drafts, certificates of deposit, acceptances, and notes. Is the elearing houce is not a collection agency, the items must be matured. Bonds and coupuns are nut permitted. Furthermore, items with pass books, bills of lading, or other locuments attached are not clearable. See SpanR, op. cit. supra note 1, at 391. The New Yurk Clearing House Association has introduced an exchange for the clearing of coupuns. See Mltsin,

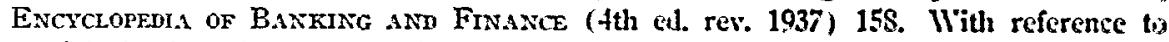
special clearings for stock certificates, see AgGer, Oranstzed Bavking (1918) 105; 2 Conant, Money ano Banking (1905) 248; Spann, up. cit. supra note 1, at te6; Stnert, Stock Cleirting Corporation: Describtion of Operition (1921); Nayec, Shock Ferchange Clearing Houses (1893) \& PoL. SC. Q. 252.

41. Although it is theoretically possible that the amount of credits to a bank will equal the amount of debits against it, only one instance of this fhemumenon has lixen revealed in the literature examined. This occurred in the Harrisburg, Pennsylvania, Clearing House Association. An equally astounding result, considering the enormous, volume of clearings, took place on November 19, 1906, at the New York Clearing House, when one of the member banks brought checks totaling $\$ 9,049,255.8 \mathrm{~s}$ and receivel cheets totaling $\$ 9,049,255.40$, giving it a credit balance of 48 cents. Sce $(0 \mathrm{ct}$. 1935) $28 \mathrm{I}$ (1) ING 66.

42. See Sp.lHR, op. cit. supra note 1 , at 402 .

43. In fact, under present conditions it would he inconceivable. Even in 1019, Professor Spahr demonstrated the impracticability of specie settlement. Taling Decembsr 16,1919 , as his date, he found that the balances to be settled at the New Yurl: Clearing 
Small wonder, then, that at an early date the banks devised a morc satisfactory means of settlement. Even before the establishment of the clearing house, five New York banks entered into an arrangement whereby each deposited money with the Mechanics' Bank, against which that bank issued certificates which in turn were acceptable as payment. ${ }^{44}$ And in 1857 the New York Clearing House banks created a similar fund in the Bank of America, and, for the most part, paid their clearing house balances by certificates issued against it. ${ }^{45}$ The certificates were in the amounts of $\$ 500, \$ 1000, \$ 5000$, and $\$ 10,000$, and contained a recital that thie Bank of America had received the amount of the certificate in specie, and held the same in trust, payable only to the order of a bank belonging to the association, on presentation, indorsed by such bank. ${ }^{40}$ Payments were made also in United States Treasury certificates of deposit payable to bearer. In 1888, the Secretary of the Treasury agreed to issue certificates of deposit payable to the order of any bank depositing gold coin with the Treasury. These instruments were indorsed by the

House amounted to $\$ 135,234,928$, and that to settle these balances by transporting gold to the clearing house would have required 45.4 five-ton trucks. Id. at 405 .

44. See (1892) 6 BaNK. L. J. 90.

45. See 2 Conant, Money and Banking (1905) 242. In Peoples Sav. Bank v. First Nat. Bank, 102 Wash. 436, 439, 173 Pac. 52, 53 (1918), the court describes a similar method obtaining in the Seattle Clearing House Association. See also Bankind Fundanentals (Am. Institute of Banking, 1925) 98; Cannon, Cleaming Housus (1910) 37. Apparently payment by certificates did not entirely displace payment by cash. See Cannon, Clearing Houses and the Currency in The Currency Problem anu the Present Financtal Situation (1908) 104; (1892) 6 Bank. L. J. 90. The following table, for example, gives the amounts of the various media used for the settlement of balances at the New York Clearing House for the fiscal year ending September 30, 1904:

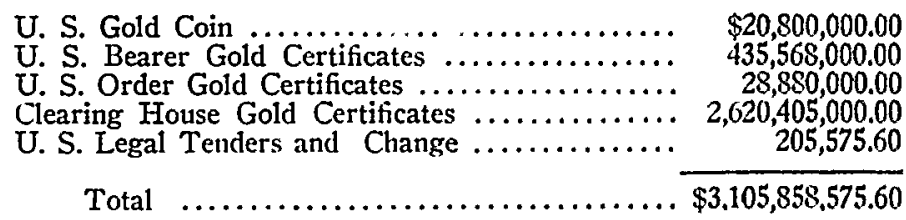

The figures are taken from Gilpin \& Waltace, The New York Cidenting Housi: (1905) 10.

The issuance of clearing house certificates is not the issuance of currency in violation of law. See Crane, Parris \& Co. v. Fourth St. Nat. Bank, $173 \mathrm{~Pa} .566,578,34$ Atl. 296, 298 (1896), in which the court said: "The use among themselves of a certificate or other representative of money to save the inconvenience and labor of counting and recounting several millions of dollars daily is not the issuing of currency. It is not a violation of the law." It has been said that since the adoption of the Federal Reserve Act the issue by clearing houses of certificates against deposits of gold has gone forever, because the federal reserve banks have absorbed the unrelated gold reserves and merged them into a common reservoir. Law, The Clearing House as a Poteer in $W^{\prime}$ ar and Prace (1918) Proc. Clearing House Sec., Am. Banikers' Ass'n 620, 625.

46. See Cleaveland, Banking System of New York (1857) 274-75. 
bank to whom first issued, and were stamped payable to any member of the clearing house association. They were valid only in clearing house settlements or for payments directly between the member banks. They superseded the certificates issued by the Bank of America, which were retired. ${ }^{47}$ The payments were made by the debtor banks to the clearing house, coin or bank notes being used for amounts less than $\$ 500$. Shortly after the debtor banks had thus settled. the creditor banks appeared and received payment from the clearing house manager or his representative."s

Improvement though it was over the cash payment method, the scheme of settlement by certificates of deposit fell considerably short of the summum bonum. It remained for the Federal Reserve System to inaugurate a plan of settlement which for simplicity cannot be excelled. The Federal Reserve Act requires all member banks to maintain reserves with their federal reserve bank. ${ }^{40}$ Thus it is possible to make settlements of clearing house balances by merely debiting or crediting the account of the bank in question upon the books of the applicable federal reserve bank. This method was adopted in New York in March, 1917.50 It has spread to most if not all of the cities boasting a federal reserve bank or branch thereof. ${ }^{51}$

In some cities which have adopted this plan there are clearing house member banks which have not joined the Federal Reserve System. Most clearing house associations require such banks to maintain a balance with the local federal reserve bank or branch, in order that the debit and credit settlements may embrace all the members of the association. ${ }^{-2}$

47. See Smyth, The New York Clearing House (1S91) 5 Batsh. L. J. 99, 101; (1892) 6 Bank. L. J. 90. But of. the table from Ginrin \& W.LLnce, supra note 45.

48. Cleaveland, op. cit. supra note 46 , at 275.

49. For the provision in the original Federal Reserve Act, see 38 Sr.tr. 270 (1913). For the act in its present form, see 40 Sr.1T. 239 (1917); 40 Srat. 970 (1918), 12 U.S.C. $\$ 462$ (1940). See Jones, Clearings and Collections; Foreitin awd Dongestic (1931) 263; SPAHR, op. cit. supra note 1, at 402.

50. See Sparr, op. cit. supra note 1, at 402; Westerfield, Banking Pamenules AND Practice (rev. printing 192S) 473. The New York Clearing House constitution authorizes payment also in various forms of United States tender or clearing house certificates, but in practice settlement is made on the books of the Federal Reserve Bank of New York. See page 4 of the pamphlet, Inforsution: Regaroma tue Orenatron of THE NEw YoRK Clearrang Hovse (1938), based upon an address by Edward L. Becl, its manager; Munn, Encyclopedia of Banking and Finarsee (4th ed. 1937) 159. Under the book settlement method, the clearing house manager merely sends a certified list of the day's balances to the federal reserve bank, which makes the credit and debit entries accordingly. See SPAHR and Westerfield, sugra.

51. See Dunbar, Theory axd History of Banking (5th ed. 1929) 48; Josies, loc. cit. supra note 49. Provisions are ordinarily made for the deposit of alditional funds by a bank whose credit at the federal reserve bank is insufficient to meet its clearing house debit balance.

52. Jones, loc. cit. supra note 49; Banknig Fundaseritals (Am. Institute of Banking 1925) 98. New York makes the requirement mentioned. See SPArr, op. cil. 
Even in cities where no federal reserve bank or branch bank is located, it is perfectly feasible to settle clearing house balances by transfers on the books of the federal reserve bank or branch serving the territory involved. The only difference is that the clearing house manager telegraphs or telephones the debits and credits, instead of causing them to be delivered by hand. ${ }^{53}$

Although the system of settlement on the books of the federal rescrve banks is widely used, it was stated not so many years ago that probably the most common method of settlement, from the standpoint of the country as a whole, was by check or draft on some institution in one of the financial centers. ${ }^{54}$ Certainly the statement no longer applies to those cities in which a federal reserve bank or branch is situated. $\Lambda$ ud, as has been seen, a number of other cities employ the federal reserve bank bookkeeping settlement by invoking the aid of the telegraph. But it is probably true that the most common practice in the smaller cities is to pay by such checks or drafts. ${ }^{55}$ New York exchange is quite generally acceptable among banks in the United States, and the exchange of various other financial centers has at least a limited acceptability. Since the so-called country banks ordinarily maintain balances in some institution in one or more of the large cities, it is a simple matter for them to make payment in the manner indicated. ${ }^{56}$

In some cities payment is made directly to the clearing house and the clearing house pays the creditor banks. ${ }^{57}$ Where payment is by cash, clearing house certificates, or book credit and debit, the clearing hotsse need not maintain an account of its own in any bank. But where clebtor

supra note 1, at 402. According to the Boston Clearing House Association rules, nonmembers of the Federal Reserve System pay by clieck on the Federal Reserve Bank of Boston, or in 'cash, or in whatever other manner the Federal Reserve Bauk of Boston approves; and non-members are paid by check on the Reserve Bank or in some other manner approved by it. Several clearing houses within the Second Federal Reserve District, which settle through the books of the Federal Reserve Bank of New York as to members of the Federal Reserve System, provide for settlement by non-members through their New York correspondents who are memlers. See Jones, op. cil. supra note 49, at 273.

53. See SPAhr, op. cit. supra note 1, at 402, 404, 534; Rel. livil. Res. Bo. (1920) 388. at 476 .

54. See Spahr, op. cit. supra note 1, at 534; Westrkithi.b, op. cil. supra note 50,

55. See the authorities cited supra note 54. See also Casson, Cleaning Housps (1910) 37; Jones, Cleearings and Collections; Foneign and Donestic (1931) 204.

56. Mr. Conant stated that the New England banks customarily settled with draits on New York or Boston, and other banks east of the Mississippi River with drafts on New York. 2 Conant, Money axd Banking (1905) 244-46. Sce also Walken, Money, Trade, and Banking (1882) $60 \mathrm{n}$. Cf. Wolfe, Settlement of Clearing Hlonse Balantes (1915) Proc. Clearing House Sec., Am. Bankers' Ass's 472, 474, predicting the adjustment of this method by reason of the Federal Reserve Act's mandate that balances in banks other than federal reserve banks and their branches may not be counted as part of a bank's legal reserve.

57. See Banking Fundamentals (Am. Institute of Banking, 1925) 98. 
banks pay to the clearing house by check or draft, and the clearing house pays creditor banks in the same manner, the clearing house must maintain an account. ${ }^{\text {s8 }}$

In some cities the clearing house manager draws against the debtor banks in favor of the creditor banks. The creditors then receive payment directly from the debtor banks. ${ }^{50}$ If for each amount owed by a debtor bank there was exactly the same amount owed to a creditor bank, the clearing house manager's task would be easy. For example, if against bank $A$ there stood a debit of $\$ 50,000$, and in favor of bank $B$ a credit in the same amount, the manager would draw his manager's check for $\$ 50,000$ on $A$ payable to the order of $B$. and so on through the list. But such simple situations do not occur. On the contrary, the manager has before him a list of debits which do not correspond, one by one, with the list of credits. To obviate the problem, he draws his first check against the largest debtor in favor of the smallest creditor, and so on down the line until the last check settles the last residue due to a creditor bank. ${ }^{60}$

One further method of settlement formerly employed by the Boston Clearing House, and, in a modified form, by Pittsburgh and some others, deserves mention. This was the borrowing and lending of clearing house balances at the close of the day's exchanges. ${ }^{61}$ The lender would give to the borrower an order on the clearing house in the amount of the loan. The borrower would use this order in settlement of its debit balance, and, since the clearing house owed at least the amount of the order to the lender, the order would be honored by the clearing house. The result was the same in essence as though the lender had delivered cash to the borrower to enable the latter to make payment. It has been pointed out that at any subsequent time. without a moment's warning, the lender, wishing to be repaid, might send a cleck through the clear-

58. "The bank acting for the clearing house receives from each bank from which a balance is due the clearing house its check on its Boston correspondent for the balanse due the clearing house, and the clearing house bank gives to each bank that has a balance due it from the clearing house its check on its Boston correspondent for that balance" Walker, Money, Trade ano Bankino (1882) 00, n. 1. Cf. Wlluls \& Enwands, Bankng AND Business (rev. ed. 1925) 238 (system whereby each memler bank teeps balance with clearing house and draws against it).

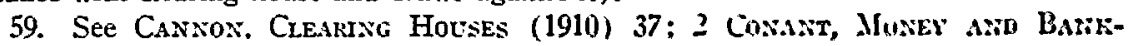
ING (1905) 244; Wilis \& Epwards, op. cit. supra nute 58, at 240-47; Ba:axiag FunDaxextals (Am. Institute of Banking, 1925) 98 . The variuus media uf payment have already been discussed. Sometintes the creditor bank nerely sends the manager's cheel: through the next day's clearings. Sec C.xsox and Civast, supra.

60. See Whils \& Edwards, op. it. supra note 58, at 247; Comaremenu Basi: Managexent: Citx Cleariaghouses (booklet issued without date by Banl: Management Commission, Am. Bankers' Ass'n) 10 it sia.

61. See Caxnos, op. cit. supra note 59, at $247 ; 2$ Conant, op. cil. supra note 59, at 244-46; Holdsworte, Money .avd Baxking (1916) 205-06. 
ing house which would so affect the borrower's clearing balance as to make payment impossible. But apparently no losses ever occurred from the practice. ${ }^{2}$

Returns. Because the clearing work is done by human beings it sometimes happens that items will be sent to the wrong drawee bank; that they will lack an essential indorsement or be irregular in some other respect; or that they will be ineligible for clearing under the rules of the association. Likewise, items may be drawn by persons whose accounts are overdrawn or who have no account with the drawee bank; or the drawer's or an indorser's signature may be forged; or the drawer may have entered a stop payment order on a certain check. As has been noted in the description of the clearing routine, the packages of items are not opened at the clearing house, and all items enclosed in a package are charged against the particular bank. Thus each bank must have a subsequent opportunity to examine the items charged against it, and some means must exist for reimbursing a bank for charges improperly made. Since the proof and the settlement are made upon the basis of the packages delivered at the clearing, the rectification of any errors must be effected extrinsically. Two possibilities come to mind immediately. The bank against which the improper charge was made may return the item to the bank which presented it, receiving payment therefor from the latter bank; or some arrangement may be devised whereby the item is charged back at a subsequent exchange.

Undoubtedly the method employed at first consisted of direct return by messenger. But more recently a number of clearing houses have established a special clearing for return items, thus simplifying the procedure in much the same way that the clearing house simplified the method of direct presentation of all items. ${ }^{63}$

So far as my investigation has disclosed, most, if not all, clearing houses have a regulation to the effect that errors in the exchanges and claims arising from the return of items shall be adjusted directly between the banks involved, and not through the clearing house. One might suppose that this requirement was intended to preclude settlement of return items through the exchanges. But that is not correct, for the clause is to be found in constitutions and regulations providing for return item exchanges. Evidently the clause merely means that a bank discovering a return item cannot look to the clearing house manager for

62. See Cannon, op. cit. supra note 59, at 247 et seq. Mr. Cannon states that at one time sixty per cent of the total balances at the Boston Clearing House were settled by the borrowing of balances, but that even by 1910 the practice had been largely discontinued. Good summaries of the various methods of settlement appear in Sisur, op. cit. supra note 1, at 99; and in (1892) 6 BANK. L. J. 90.

63. See (1918) Proc. Clearing House Sec., Am. Bankers' Ass'n 603. 
reimbursement. This interpretation renders the provision in question consistent with that creating a return item exchange.

Sereral of the clearing house associations under examination require that all return items be brought directly to the bank which presented them, and of course specify a time limit, usually early in the afternoon of the day on which the items were cleared. Several uthers have created a special exchange for return items, but have given the banks the option of returning the paper directly or through the exchange. Cleveland and St. Louis have return item exchanges which apparently supersede the direct return method and are exclusive except as to certain situations. ${ }^{\text {at }}$

The matter of settlement for return items remains for consideration. With reference to payment for direct returns, the majority of the associations studied lay down no specific rules. Presumably, in such associations, payment is made upon the same basis as in the case of any other obligation owed by one bank to another. A few assuciations, on the other hand, cover the point. Boston stipulates the debtur banl's own check or due bill or a check on the Federal Reserve Bank of Boston, at the claimant's option. Milwaukee and Syracuse specify clearing house funds, the latter adding "or as may be otherwise agreed." New York, in connection with direct return of missent and ineligible matter, requires reimbursement, in lawful money or clearing house certificates, ur through the Federal Reserve Bank of New York. Philadelphia designates law ful money, authorized certificates, or draft on the Federal Reserve Bank of Philadelphia, at the option of the creditor bank.

In associations holding exchanges for return items it is matural to find the matter of settlement specifically regulated. The Detruit and St. Louis constitutions merely state that settlement shall be the same as in the main clearing. The Tulsa association settles by clearing house manager's certificates, payable the same day. The most popular method appears to be by receipts or due bills. Under this arrangement, each bank bringing return items to the clearing receives from each bank to which it brings any such itens a receipt or due bill for the amuunt thereof. The bank holding the receipt or due bill then includes it in the regular clearings of the next day.

The London Bankers' Clearing House. ${ }^{65}$ The clearing house in Londun is known as the London Bankers' Clearing House. The differences in

64. Some of the larger clearing houses have quite detailed frovisiuns classifying? items and stipulating the procedure to be followed fur each class.

65. Described in Grant, Bankers and Banking Conpasies (7th (J. 1924) 70;

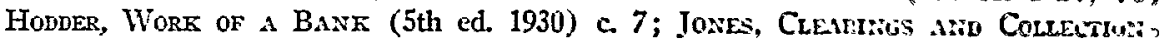
(1931) c. 2; Matthews, The Bankers' Clearing House (1921) c. 3; (1592) o Basit. L. J. 32, 34; Boddington \& Davis v. Schlencher, 4 Bar. \& .1d. 752, 753, 110 Eng. Rep. 639 (K. B. 1833) ; Warwick v. Rogers, 5 Mlan. \& G. 340, 348, 134 Eng. Rep. 595, 5:\$ (C. P. 1843). 
procedure, together with the fact that the London organization was really the parent of the clearing house plan, warrant a description of its routine. ${ }^{66}$ I shall deal only with the Town Clearing, which handles items drawn on the.clearing bankers and their nearby branches. ${ }^{17}$

It will be recalled that in the United States the clerks engaged in the business of the exchanges are known as delivery clerks and settling clerks. In London they bear the name of clearers, which concept is divided into "in clearers" and "out clearers." Each bank has two sets of books: one, known as the "out clearing" or "to receive book," for the entry of checks to be presented against the other banks; the other, called the "in clearing" or "paid book," in which are listed the checks brought against the bank in question. ${ }^{68}$ In each book the pages are ruled into columns, and at the head of each column is the name of one of the banks. The arrangement is alphabetical in order to make the clearer's work easier and more rapid. The out clearer make the entries in the out clearing book, and the in clearer in the in clearing book, with one exception to be noted subsequently. In the morning or the previous evening the out clearers sort into piles the checks to be presented against the various banks, and arrange the piles in alphabetical order according to the names of the banks. ${ }^{60}$ This done, the out clearers cuter the checks in the out clearing books, under the names of the respective banks. When the checks against the first bank have all been entered, the clerk computes and enters the total, fastens the checks together, and writes the total on the back of the last check. He then follows the same procedure with the next batch of checks; and so on until completion. All this work the clearer performs at his bank. He next takes his checks and out clearing book to the clearing house. At this point a vast difference appears between the English and American technique. Whereas in this country the exchanges take place with military precision in a few moments, in London they occupy a substantial portion of the day

66. Due to present world conditions I deemed it inadvisable to conmunicate with the London Bankers' Clearing House in order to learn of any rccent changes in procedure.

67. See Schenck, The Evolution of the Clearing House (1907) 10. The exten= sive use of the branch banking system in England produces many problens not found in the United States. These are beyond the scope of the present article except insofar ats they coincide with regular clearing house procedure. In 1907 the Mctropolitan Clearing was established for the purpose of improving the handling of checks drawn on more remote Greater London branches. On this subject, see GRANT, op. cil. supra note 65 , at 73; MAtruews, op. cit. supra note 65, at c. 5. The Country Clearing Section of the London Bankers' Clearing House takes care of checks drawn on banks and branches outside London. See Matruews, op. cit. supra note 65, at c. 4; (1884) Proc. $\Lambda \mathrm{M}$. BANKERS' Ass'N 81.

68. The word "checks" is used in a generic sense, and is meant to include all other types of paper eligible for clearing.

69. As to interbranch procedure, see MatTHEws, op. cit. supra note 65, at 40. As to the membership of the Bank of England in the clearing house, see id. at 35 . 
and are not synchronized. ${ }^{70}$ For instance, the morning clearing worl: goes on for the better part of two hours. Although the authorities are not uniform with reference to the exact time stipulated for the morning clearings, the clerks apparently are in session at the house frum about ten until twelve. In the first place, as already indicated, they do not make the exchanges simultaneously. They begin to arrive about ten o'clods, and by approximately eleven the actual exchanging of checlis must be completed. Upon arrival the clerk delivers the items held against the rarious banks, going from desk to desk in alphabetical order. When, a few moments later, a clerk from another bank arrives, he follows the same procedure.

The in clearer of each bank presides over that bank's clearing huuse desk. To his desk he has taken his in book. When the out clearer of a given bank (say bank $A$ ) deposits his batch of checks upun the desk of Bank $B$, the in clearer of the latter institution enters them checl: by check in the column headed with bank $A$ 's name. He then adds the column and compares his total with the total appearing un the back of the last check - the figure having been placed there by bank A's out clearer, as already explained. In like manner all batches of checks brought to the in clearers are entered, totaled, and compared with the total furnished by the out clearer on the back of the last item.

Suppose that the bank $B$ in clearer's total differs from the figure on the last check. In such event the in clearer "sings out" in a loud voice the name of bank $A$, and the bank $A$ clerk carries his ont hook to $B$ 's desk, where the two representatives put their heads together, check the items, and correct the mistakes.

After all entries and corrections have been made, the in clearer returns to his bank, taking with him the checks drawn against it, together with the out clearing books. He leaves the in books on his desk at the clearing house. At his bank he turns the batches of checks over to that part of the clerical force assigned to the task of examining the checlis for regularity, forgeries, and the like, and of looking up the state of the depositors' accounts. ${ }^{71}$ Checks which meet the test are debited to the drawer's account. Those which do not, i.c., the returns, are dealt with in the manner set forth below.

From the above description, it becomes apparent that, in contradistinction to the system employed in the New York Clearing House and its progeny, no balances are struck at the morning clearings in London. On the contrary the totals of the morning clearings are carried forward to the afternoon clearing, and the latter is really a continuation of the former.

70. See Gilpin \& Wallice. The New York Cleiring House (1905) 30.

71. For a detailed description, see HoDdER, of. cit. sulpra note 65 , at 69; and for interbranch procedure, see MatThElvs, op. cit. supra note 65 , at 31. 
The afternoon clearing is even less regimented than the morning. From approximately two-thirty until approximately four, runners are speeding to-and-fro between the banks and the clearing house, bringing items against other banks and returning with items against their own. The items to be sent to the clearing house are first entered at the bank by the out clearer in his out book. Some of these may be returns, representing bad checks, received either in the morning exchanges or through the afternoon deliveries. These returns are charged in the out book in the same manner as original items. They are placed face downward in the check piles in order to focus the in clearer's attention on the fact that they are returns.

As the afternoon items are received from time to time at a partictlar in clearer's desk at the clearing house, the in clearer enters them in his in book to the credit of the bank bringing them. If the item chances to be a return, he marks an " $R$ " opposite the entry. He has no right to refuse to accept a return and to pass it to the credit of the proper bank, provided the reason for the return is marked on it. As soon as the charges are entered, the runner takes the checks to his bank for examination.

About five minutes before closing time, the out clearer, having entered and sent to the clearing house all the items for the day, closes his out books and departs with them for the clearing house. At closing time a bell is sounded, and no more checks may be brought that day. The in clearer, having entered the last charges against his bank, now totals the amounts. By this time the out clearer has arrived. He hands over his out books to the in clearer.

Ten minutes after the closing of the doors they are reopened to permit the runners to rush back to their banks with the last lot of items. These are examined by the drawee bank to see whether or not they are good.

The in clearer next proceeds to make a balance sheet. He places his out book to his left and the in book to his right. To understand the preparation of the sheet, a general idea of its form is set forth below:

\section{THE B BANK}

Debtors

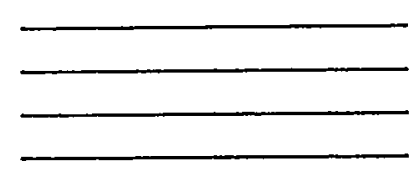
A Bank
C Bank
D Bank
E Bank

Creditors

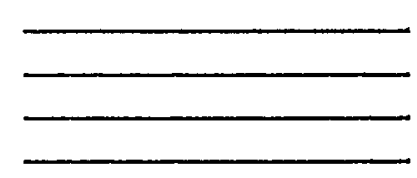

The clearer looks at his out book to see the total charges which his bank has against the $A$ bank. He then looks at his in book to see the total charges which the $A$ bank has against his bank. He strikes a balance. If the balance is in favor of the $A$ bank, he puts the amount 
in the "Creditors" column on his sheet, opposite the name of the $A$ bank. If the balance is in favor of his own bank, he enters the amount in the "Debtors" column. He makes a similar computation for each bank and totals the two columns. When he has finished, his sheet will show his bank's position for the day with regard to each other bank, as well as the total debits and credits.

Having completed his sheet, with certain exceptions to be considered later, he takes his out and in books and proceeds around the room to each other bank's desk, checking his balance with theirs.

Meanwhile the runners have come back to the clearing house with any returns growing out of the last batch of items. The $B$ bank's runner brings his bank's returns to his in clearer. That gentleman adds up the total amount of these returns and enters the sum in the "Debtors" column of his sheet below the total previously obtained. He then obtains the final total for this column by adding the previous total and the returns. The return items are then sent to the desks of the banks against whom they are to be charged. Thus, as $B$ 's clearer sits at his desk, he will receive the returns sent to his bank from other banks. He adds these, and, since the amount constitutes a charge against his bank in favor of the returning banks, he enters the amount in the "Creditors" column of his balance sheet under the previous total. At a certain time the bell rings again, whereupon the clerk totals the "Creditors" column and strikes a balance between the two columns. This balance will show whether his bank is a debtor or creditor at the clearing house for the day's transactions.

The clerk then enters on a small printed form his bank's credit or debit balance for the day, and fills out a ticket addressed to the Bank of England, directing that institution to make the proper debit or credit on its books. This ticket is taken to the Bank of England, with which all members are required to keep an account. The entry is made, and the curtain falls upon the day's drama. ${ }^{72}$

\section{Benefits of the Clearing House}

At the risk of some repetition, it will be helpful to enumerate the more important improvements resulting from the clearing house method of local check collection. ${ }^{73}$ First, there is the saving in time and labor in the delivery of the checks. Instead of visiting every other bank, the

72. Certain details, such as certification by the clearing house inspectors, are omitted from my explanation, which is meant to give the more escential features. Originally, balances were settled by Bank of England notes and coin.

73. Good summaries appear in Cleaveland. Binsmig Systens of New Yons: (1857) 275; Hallock, Clearing Out-af-Towa Checks (1903) 9; Spams, of. cir. sutpra note 1 , at $\mathrm{S1}$. 
messenger now takes all his checks to the clearing house, and there receives all the checks drawn against his bank. Before the establishment of the clearing house, the exchanging of checks often consumed half a day in the New York area. With the advent of the clearing house, this was reduced to a few moments. ${ }^{74}$ Secondly, there is the saving in bookkeeping. With the creation of the clearing house came the abolition of the individual accounts with each of the other banks and the substitution therefor of one account, namely, that with the clearing house. . $^{5}$

Finally, important economies and improvements have resulted in connection with the payment of obligations. The labor, drudgery, irritation, and annoyance arising from the activities of a number of bank messengers making payments to the individual banks have disappeared. Settlement at the clearing house involves only one trip and, for the creditor banks, the receipt of only one payment. Likewise, the necessity of paying only the clearing house debit balance instead of making a number of payments to the individual creditor banks, reduces the amount of reserve, the quantity of cash, and the distance to be covered by the messengers engaged in the risky business of carrying currency. ${ }^{76}$

\section{The Efrect of the Federal Reserve System on the Local Clearing House}

With the adoption of the Federal Reserve Act, ${ }^{77}$ the future of the local clearing house as the clearing agent for intracity collections became the subject of speculation. One writer, discussing the matter shortly before the passage of the Act, pointed out that the Federal Reserve Board might assume either directly or through the fecleral reserve banks a large part of the clearing house functions of the whole country so far as member banks were concerned, "and thereby reduce all existing clearing house associations to minor organizations for clearing the remaining volume of checks on banks not members of the system." "78

74. See Cannon, Clearing Houses (1910) 55; (1880) 11 Cent. L. J. 462.

75. In New York, this resulted in the closing of 2,652 accounts. See Haltow, loc. cit. supra note 73 .

76. For the period from 1854 through 1938, the ratio of balances to clearings at the New York Clearing House was approximately 91/2\%. See ManaGer's ANNust. REPORT (1938). In cities like New York, where settlement no longer is made in currency, the risk involved in carrying currency is eliminated.

77. The Federal Reserve Act became law December 23, 1913. The original Act is in 38 Stat. 251 (1913). The Act, as presently amended, is in 12 U. S. C. $\$ 221 \mathrm{ct}$ set. (1940). Subsequent amendments appear in the supplements. Sections 13 and 16 of the original act were the applicable ones.

78. See Talbert, Clearing-House and Domestic-Exchange Functions of the Fedcral Reserve Banks (1913) 4 ACAd. of Poz. Scr. Proc. 192, 194-95. See also Holdswoktri, 
It would certainly appear feasible for the several federal reserve banks to take over the local clearing functions in the cities of their respective habitats, at least so far as member banks are concerned. U'sing Cleveland for illustrative purposes, the routine would be somewhat as follows: $A$ has his account in The Cleveland Trust Company. He draws a check payable to the order of $B$, who banks with The National City Bank of Cleveland. $B$ deposits the check to his credit in The National City Bank. At present the latter bank places the check with the batch of clearing house items drawn on The Cleveland Trust Company, and the check goes to the clearing house, is charged against The Cleveland Trust Company, and winds up at that institution, where $A$ 's account is debited. The check will be reflected in the clearing house credit or debit balance for the day, which is satisfied by entries on the books of the Federal Reserve Bank of Cleveland. If the latter undertook the clearing functions, The National City Bank would send the check to the Federal Reserve Bank, and that bank would credit The National City Bank's account, debit The Cleveland Trust Company's account, and send the check to it. The Federal Reserve Bank could very easily adopt the necessary rules covering the time at which items must be delivered, the packages in which they must be placed, the manner of listing, and the like. In fact, the Reserve Bank might even require that the representatives of the member banks exchange items as they do under the present system. In this event, no substantial change in method would have occurred, but the Reserve Bank would have succeeded the local association as the clearing agent. In federal reserve cities containing banks not members of the system, however, the problems arising in connection with the non-member banks would seem to preclude the federal reserve bank from supplanting the clearing house association. ${ }^{70}$ Indeed, the Secretary of the Clearing House Section of the American Bankers' Association recognized this, when he stated:

"While it is provided that the federal reserve banks may, in time, assume the functions of the clearing house entirely, I think

Money and Banking (1916) 212; Conway \& P.tTerson, Operation of the New BANK ACT (1914) 328.

79. Section 16 of the Federal Reserve Act, 38 STAт. 265 (1913), 12 U. \$. C. $\$ 24 \$(0)$ (1940), authorized the Federal Reserve Board, at its discretiun, to require each federal reserve bank to exercise the functions of a clearing luuse for its memler banls. Sectiun 4 of the Act, 40 STAT. 234 (1917), 12 U.S. C. $\$ 3+2$ (1940), amending Section 13 of the original Act, allowed any federal reserve bank to receive checks, etc., fur exchange or collection from any non-member bank or trust company, pruvided the nun-member bank or trust company maintained with the reserve bank of its district a halance sufficient to offset the items in transit held for its account by the reserve bank. It is ubvious, and has been a fact, that some banks might not wish to become a part of the Federal Reserve System as either members or clearing non-members, whereas they might willingly juin a lueal clearing house. 
that time depends on the period when all banks are members of the Federal Reserve System. It is quite likely that the federal reserve banks will not operate as local clearing houses until all banks are members. Furthermore, the federal reserve banks will probably be local members of the clearing house . . ."80

Moreover, in a city located at any appreciable distance from a federal reserve bank or branch, the substitution of the federal reserve bank for the local clearing house would prove most undesirable, even though all the banks had joined the Federal Reserve System; for a bank holding a check on another bank in the same city would be compelled to send it by mail to the federal reserve bank, which, in turn, would mail it back to the drawee bank - a procedure the uneconomical nature of which, compared to that of the clearing house, is readily apparent.

Evidently appreciating the situation, the Federal Reserve Board announced at the beginning that its plan of intradistrict clearances would not apply to or supersede local clearings in clearing house cities, since the clearing houses already provided the necessary machinery; and the circulars dispatched by the federal reserve banks to their members, announcing the inauguration of the plan, advised them that the reserve banks would not handle checks between banks located in the same clearing house city. ${ }^{81}$ This policy has continued throughout the life of the Federal Reserve System. ${ }^{82}$ As already pointed out, however, the system has afforded to clearing houses an opportunity to effect settlement of balances by debits and credits upon the books of the reserve banka distinct boon to such organizations.

Since the federal reserve bank or branch in a given city will receive many checks drawn on banks in the same city, membership in the local clearing house becomes advantageous to it in the collection of such checks. Recognizing this, clearing house associations have admitted the local federal reserve bank or branch, under special arrangements. Customarily, the reserve bank has no vote or voice in the management of the association, is not subject to the examinations or reports often prescribed for the association members, and need not sign the constitution

80. (1914) Proc. Clearing House Sec., Am. Bankers' Ass's 496.

81. See Agger, Organized Banking (1918) 290; (1915) 23 J. Pol. Econ. 392, 393 ; id. at $507-08$.

82. It is true that on July 15, 1916, the Federal Reserve Bank of Boston to at certain extent took over the operation of the Boston Clearing House Association. The Reserve Bank furnishes the equipment and employs the clearing house clerks. Yet the Association continues its status as a voluntary organization, maintaining supervision over its members and conducting the daily clearings. Thus, actually the Reserve Bank merely extends its aid to the Association. See AGGER, op. cit. supra note 81, at 294. Ser* eral bank officers have confirmed my conclusion that the Federal Reserve System has not superseded the local clearing house. 
or articles of association. Usually the bank must help bear the expenses of the association, although not to the same degree as the members; and a common method is to leave the amount to the determination of the clearing house committee. ${ }^{83}$ Inasmuch as the reserve bank enjoys the clearing privilege, it is required to abide by the clearing rules, including such matters as time for exchanging items, form in which items are to be brought to the exchanges, time and manner of returns, and the like. ${ }^{84}$

83. Mrr. Warburg, who served as a member of the Federal Reserve Board, foresaw the benefit to be derived by the federal reserve banks in joining losal clearing houses. 2 Warburg, Federal Reserve System (1930) 122.

84. The legal problems arising from the collection of checls through the clearing house are reserved for further extended treatment. 